\title{
Teaching Esp in Some Departments of the Prishtina University "Hasan Prishtina"
}

\author{
Albulena Pllana-Breznica \\ Faculty of Languages, Cultures and Communication, Master's student SEEU of Macedonia Tetova \\ Email: albulena.c@hotmail.com
}

\section{Doi:10.5901/ajis.2016.v5n1p65}

\begin{abstract}
In this paper teaching ESP at some of the different faculties of the University of Prishtina "Hasan Prishtina" will be examined and analysed. The emphasis is on the importance of teaching English for Specific Purposes and how it is going to benefit the students in their future occupations. Unfortunately ESP is not taught properly in various study directions, or instead of teaching ESP, EGP (English for General Purposes) is taught which does not meet the professional requirements of the present time. This will be shown through the available syllabi of some faculties which will allow a comparison between them. Therefore this research should serve as a motivation for all English teachers in higher education for further development and betterment of teaching ESP. It also should encourage them to share their experiences and difficulties with other teachers by organizing regular meetings where many problems of teaching ESP could be solved effectively by discussing them in a cooperative way, and it would certainly improve their future work.
\end{abstract}

Keywords: ESP, EGP, syllabi, occupation, higher education

\section{Introduction}

The "English for Specific Purposes" (ESP) approach to language teaching in view of absolute and variable characteristics in the Department of English Language and Literature at the Faculty of Philology of the University of Prishtina "Hasan Prishtina" was defined in this paper, making a comparison with some other departments of the University Prishtina. This research was undertaken to show how ESP is taught or not taught in those different departments, by comparing the used basic literature and additional materials, and it will also explain own experiences while studying English. Furthermore, it highlighted the importance and the need of teaching/learning ESP in higher educational institutions of Kosova, in order to facilitate the transition from theoretical learning into practice of the various future professions of the students. It is apparent that a deficiency in ESP teaching is still present in some departments of the University of Prishtina. The objectives of this research are to make English teacher aware of the immense necessity for teaching the students occupation-related English, so they can adapt easier in their future jobs.

\subsection{The definition of ESP}

Wright indicates that by the term English for Specific (or Special, Specified, Specifiable) Purposes is meant that type of language learning which has its focus on all aspects of language pertaining to a particular field of human activity (Wright, 1992, 3). This can be put in a simpler way: it is a kind of learning or teaching a special language, which will concentrate on the usage of it in the relevant vocational environments.

ESP is a new discipline within Applied Linguistics that offer a new learner-centred approach to English language teaching whose methodology is based on the specific needs of the learner. Kennedy and Bolitho $(1984,3)$ argue that ESP refers on „an investigation of the purposes of the learner and the set of communicative needs arising from these purposes". Mackay and Mountford (1978) indicate that the term ESP is generally used to refer to the teaching of English for a clear utilitarian purpose. A very clear definition for ESP is the one which was described by Hutchinson and Waters (1987), they pointed out that as an approach to language teaching in which all decisions as to content and method are based on the learner's reason for learning, they added also that the term ESP entail that, English is peculiar to the range of principles and procedures which define that particular profession. 


\subsection{ESP vs. EGP}

English for Specific Purposes or ESP differs in many ways with English for General Purposes, or EGP. If English is taught as a L2 the focus is more on teaching grammatical issues, orthography, pronunciation, reading and listening comprehension, translating and practising simple everyday communication, then this is EGP. On the other hand, if English is taught to students studying special fields and need a specialized communication competence with sufficient knowledge of the relevant terminology, then this is ESP.

\subsection{The Meaning of the Word 'Special' in ESP}

Perren (1974) pointed out that there is a distraction for the two concepts that include two absolutely different concepts of special language and specialized aim. Mackay and Mountford (1978) argue the idea of a special language in a more understandable way:

The only practical way in which we can understand the notion of special language is as a restricted repertoire of words and expressions selected from the whole language because that restricted repertoire covers every requirement within a well-defined context, task, or vocation (page 4).

Mackay \& Mountford, 1978 said that "A specialized aim refers to the purpose for which learners learn a language, not the nature of the language they learn". Therefore, the target of the word 'special' in ESP care to be on the purpose for which learners learn and not on the specific jargon or registers they learn.

\section{ESP Courses at the University of Prishtina "Hasan Prishtina"}

The University of Prishtina "Hasan Prishtina" is a public higher education institution located in Prishtina, Kosova and has now seventeen faculties and eighty-five departments and programs, dedicated to diverse fields of study. Since English is the top language on our planet, all these faculties along with their different departments and programs offer English courses, generally as compulsory and some of them as elective/optional courses in their curricula. In most cases those departments offer General English courses and that also of different levels, even though this shouldn't be so after ten years of English learning during the primary and secondary schooling. First of all the level should be intermediate up to advanced, and the English courses should be offered for specific purposes, according to the various fields of studies and the specific needs of the learner, in order to enable them to use English without big difficulties in their future occupational premises.

There should be mentioned a few exceptions, like the Department of English Language and Literature, the Faculty of Economics, the Faculty of Law, the Faculty of Electrical Engineering and Computer Science and the Faculty of Medicine, where ESP is offered as a compulsory and in a few cases as an optional course for the students.

\subsection{ESP courses in the Department of English Language and Literature in Prishtina}

The Department of English Language and Literature of the Faculty of Philology offers apart from General English courses special courses, like English for Academic Purposes and English for Specific Purposes, which students attend with great interest. ESP is here an optional course in the second and third year (each year for one term), where especially students, who are already aiming to become translators and interpreters, or find it attractive for other reasons, have the opportunity to gain additional knowledge about the diversity of the terminology of different fields. There is an exciting mixture of special topics from diverse fields of science, like literature, medicine, law, economics, social sciences, agriculture, electrical and mechanical engineering, natural and political sciences, etc., using numerous texts and fragments for reading comprehension, translating and then discussing them extensively in class (Gërmizaj \& Hoxha, 2014). In the scientific paper about "Teaching ESP in the University of Prishtina", Gërmizaj \& Hoxha regarding this issue, of teaching ESP at the University of Prishtina state that '... the aim of these units is of an informative and educational nature and they are usually followed by special comprehension and vocabulary check. ESP is challenging to describe and limit in linguistic terms. It has to be highlighted that there is more than one face to ESP communication with some of it being much closer to the everyday language spoken by ordinary people than many other segments of ESP. The focus is on presentation through reading and explanations, providing synonymous words, antonyms as well as homophones that are frequently encountered in English`. 
The paper presents an interesting investigation about the students' motivation and perception of the ESP courses in the Department of English Language and Literature and the Faculty of Economics, where 32 students of both were questioned about their satisfaction and their attitude towards the ESP courses they have participated. The students were asked e series of questions, like 'how much the content of the course was suitable to their needs; how much the structure and the sequencing of the course was suitable to them; if course materials were informative and educational; how they would grade their improvement of language skills during the course; how much the course has enabled them to identify their strength and weaknesses; if it was a good opportunity for self-directed, autonomous work; and if the ESP course has met their expectations'. Analysing all the students' statements of this survey, it can be concluded that the mass responded very positively about the offered ESP courses.

\subsection{ESP courses at the Faculty of Economics in Prishtina}

The Faculty of Economics offers ESP courses in the first and second year, respectively in the first and fourth semester of Bachelor studies. In the first term it is offered as a compulsory course, while in the fourth term as an optional course.

According to the author of "English for Business Studies", Ian Mackenzie, the courses aim to:

- present the students with the language and concepts of business and economic found in books, journals, newspapers and magazines, and on websites;

- develop their comprehension of business and economics texts;

- develop their listening skills in the fields of business and economics;

The syllabus of the first year of study covers the most important areas of management, production and marketing, divided into 14 units, enabling the students to build vocabulary through reading, listening and speaking, and to improve their confidence and fluency in expressing themselves in speaking and writing about the diverse topics related to business and economics.

The syllabus of the second year of study covers the most important areas of finance and economics, divided again into 14 units, with interesting topics like banking, bonds, stocks and shares, taxation, employment, international trade, economics and ecology, and others. The main objectives during the second year are to develop the students' general capacity to a higher level that enables them to use professional English in their future vocational and academic environment. Both courses ( $1^{\text {st }}$ and $2^{\text {nd }}$ year) are held once a week, 2 hours, one unit per week, like it has been designed by the author.

To spare the space of this paper only a fragment of the syllabus form of the Faculty of Economics will be presented here, where the literature is listed; showing the branch-oriented books, texts and other sources used during the ESP courses.

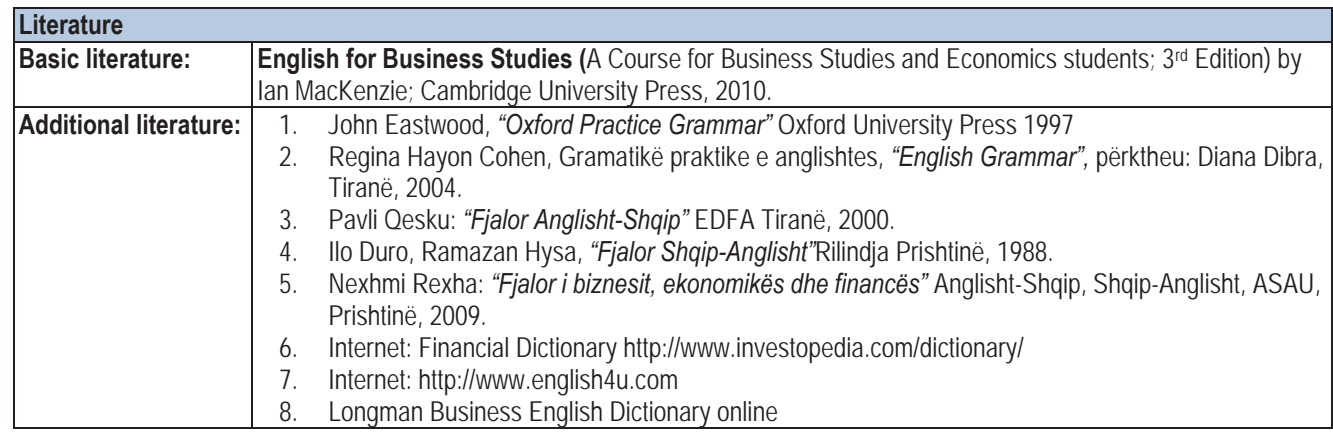

Figure 1 - Fragment of page 2 of syllabus form

The Basic English book 'English for Business Studies', containing 28 units, is an upper-intermediate to advanced level reading, listening, speaking and writing course for learners who need to understand and express the key concepts of business and economics on English. The content of this book along with the other offered sources meets the needs of economic students to deepen their language skills, as well as their expert knowledge in this foreign language, making the practical entry into the real professional world easier. 


\subsection{ESP courses at the Faculty of Law in Prishtina}

The Faculty of Law offers ESP courses in the first and second term, respectively in the first year of Bachelor studies. In both terms it is offered as a compulsory course. According to the syllabus, this course is organised in lectures, discussions about the related topics, individual work (out-of-class preparation of various topics and presenting them in front of the class), and group work, like role plays of stimulated court sessions. These courses can be considered suitable for the needs of law students, enabling them to develop and improve their language skills along with expanding their professional vocabulary and using this acquired knowledge for further autonomous researching activities by using existing literature and internet sources.

Literatura bazë/Basic literature
1. Vićan, Pavić, Smerdel - ENGLISH FOR LAWYERS, Zagreb, 2003.
2. Vesel Nuhiu - ENGLISH GRAMMAR EXERCISES, Prishtinë, 1996.
Literatura shtesë dhe bibliografia/Additional literature and bibliography
1. Alison Riley - ENGLISH FOR LAWYERS, Macmillan Publishers, 1991.
2. Tony Honoré - ABOUT LAW - An Introduction, Clarent Press, Oxford, 1995.

Figure 2 - Fragment of page 2 of syllabus form

\subsection{ESP courses at other departments of the University of Prishtina}

The following presented data about ESP courses in other departments are taken from the official websites of the academic units of the University of Prishtina, whereby it has to be pointed out that not all of the syllabus forms about the English courses were accessible, therefore only those which could be found on the internet will be presented.

- Starting with the Faculty of Philology, comprising 8 different departments, only one syllabus form was accessible on the faculty's website, that of the Department of Journalism.

As it can be seen in fig. 4, the English teacher of the Department of Journalism uses a General English book, intermediate level, as well as a professional English book for Journalists, and it is a compulsory course.

\begin{tabular}{|l|l|}
\hline Literatura (Literature) \\
\hline Literatura bazë: \\
(Basic literature) & $\begin{array}{l}\text { The third edition 'New Headway Intermediate student's and work book'; } \\
\text { Wyndord Hicks: 'English For Journalists', third edition }\end{array}$ \\
\hline Literatura shtesë: & Second language Acquisition -Rod Ellis- Oxford, University Press \\
(Additional literature) & $\begin{array}{l}\text { Teaching Written English Ronald V. White } \\
\text { Grammar Practice Activities; -Penny Ur }\end{array}$ \\
& - Fjalor Anglisht - Shqip dhe Shqip - Anglisht \\
& -Oxford English Dictionary \\
& - The A-Z of Correct English -Angela Burt \\
& -The teacher's grammar book-James D. Williams \\
\hline
\end{tabular}

Figure 3 - Fragment of page 3 of syllabus form

- The internet research about English courses at the Faculty of Medicine, comparing the used literature in its 6 departments, resulted that they use the same professional English course book (upper level) for all departments, along with General English books as additional literature. It is a compulsory course for the medical students of all directions.

\begin{tabular}{|l|l|}
\hline Literature \\
\hline Basic literature: & English Language for Medicine, dentistry, pharmacy and defectology \\
\hline Additional literature: & $\begin{array}{l}\text { 1. Grammar Spectrum III } \\
\text { 2. Headway Intermediate }\end{array}$ \\
\hline
\end{tabular}

Figure 4 - Fragment of page 2 of syllabus form

- The Faculty of Civil Engineering and Architecture with its 4 departments, use the same General English course 
book and internet sources as additional literature for all its departments, mentioned on page 1 and 3 of the syllabus form. Here the course is offered as an optional course.

Formular për SYLLABUS të Lëndës Gjuhë Angleze

(Form of the syllabus of the subject English language)

Të dhënat bazë të lëndës (Basic data of subject)

\begin{tabular}{|l|l|}
\hline $\begin{array}{l}\text { Njësia akademike: } \\
\text { (Academic unit) }\end{array}$ & $\begin{array}{l}\text { Fakulteti i Ndërtimtarisë dhe Arkitekturës } \\
\text { (Faculty of Construction and Architecture) }\end{array}$ \\
\hline Titulli i lëndës: (Title of subject) & Gjuhë angleze - Arktitekturë (English language-Architecture) \\
\hline Niveli: (Level) & Bachelor \\
\hline Statusi lëndës: (Status of subject) & Zgjedhore (Arkitekturë) (Optional (Architecture)) \\
\hline Viti i studimeve: (Year of studies) & Viti I, Sem. 1 (1' year, $1^{\text {st }}$ semester) \\
\hline $\begin{array}{l}\text { Numri i orëve në javë: } \\
\text { (Number of hours per week) }\end{array}$ & $\begin{array}{l}2 \text { orë x } 4 \text { programe - Hidroteknikë, Gjeodezi, Konstruktiv \& Arkitekturë } \\
2 \mathrm{~h} \text { x 4, Programs-Hydro-technique, Geodesy, Constructive \& Architecture) }\end{array}$ \\
\hline
\end{tabular}

Figure 5 - Fragment of page 1 of syllabus form

\begin{tabular}{|l|l|}
\hline \multicolumn{2}{|l|}{ Literatura/Literature } \\
\hline $\begin{array}{l}\text { Literatura bazë: } \\
\text { (Basic literature) }\end{array}$ & $\begin{array}{l}\text { New Headway Advanced Student's Book (2007). } \\
\text { Oxford University Press, Oxford UK. } \\
\text { Oxford Dictionary, Oxford University Press, Oxford, UK. }\end{array}$ \\
\hline $\begin{array}{l}\text { Literatura shtesë: } \\
\text { (Additional literature) }\end{array}$ & $\begin{array}{l}\text { Hulumtimi i internetit për materialet me shkrim si dhe Revista e broshura profesionale. } \\
\text { (Internet research for written materials and journals and professional brochures. }\end{array}$ \\
\hline
\end{tabular}

Figure 6 - Fragment of page 3 of syllabus form

- At the Faculty of Electrical and Computer Engineering with its 6 departments the English teacher uses professional English course books and a large number of materials taken from the internet, which are chosen according to the specific fields of study, like the Department of Computer Engineering, Dep. of Telecommunication, Dep. of Electronic, Dep. of Automatic, Dep. of Electric Power and the Dep. of Electric Power Systems. This course is an optional one; it lasts 1 term and has 5 ECTS. According to this syllabus the students will be evaluated due a seminar paper, intermediate assessment, and the final exam.

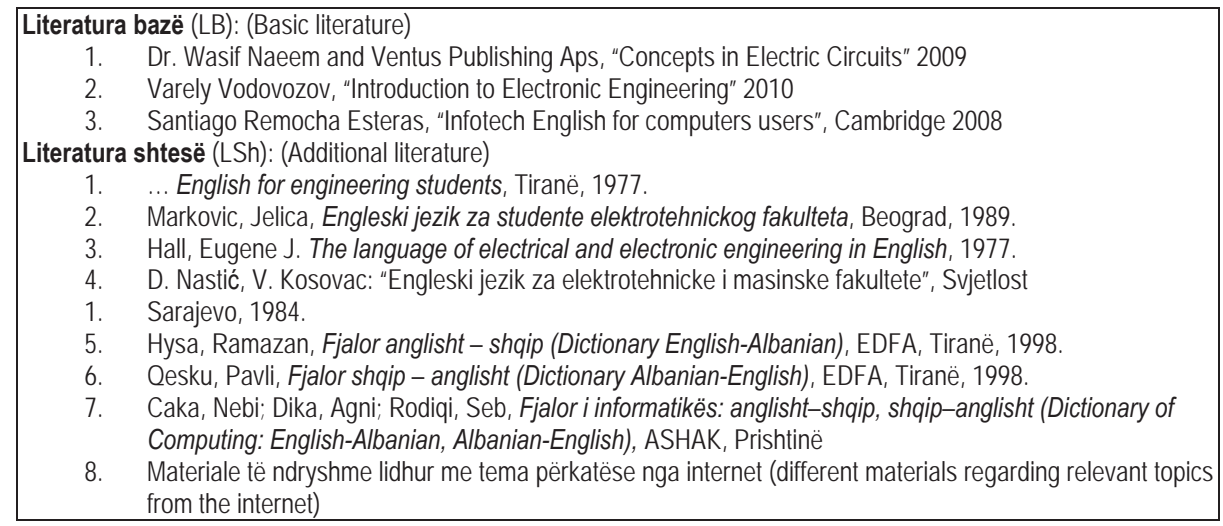

Figure 7 - Fragment of page 3 of syllabus form

- On the official website of the Faculty of Philosophy, with its 7 departments, only two departments published their syllabi of the English compulsory courses, the Department of Pedagogic-Social work, and the Department of Political Sciences on the internet.

The Department of Pedagogic-Social Work offers this course, using an elementary levelled General English course book, to its students, as shown in figure 8. 


\begin{tabular}{|l|l|}
\hline \multicolumn{2}{|l|}{ Literatura (Literature) } \\
\hline Literatura bazë: (Basic literature) & Headway elementary \\
\hline Literatura shtesë: (Additional literature) & Master the Basics English, Jean Yates, Barrons \\
\hline
\end{tabular}

Figure 8 - Fragment of page 2 of syllabus form

- The Department of Political Sciences offers this course as a compulsory General English course, dividing the students into two groups, after testing their level, and working with them on pre-intermediate and upperintermediate levels.

\section{General English Course books:}

Gude Karthy and Duckworth Michael, Matrix- Pre Intermediate Students Book, Oxford University Press

Gude Karthy and Duckworth Michael, Matrix- Pre Intermediate Workbook, Oxford University Press

Figure 9 - Fragment of page 2 of syllabus form

After collecting all these available information about English Language Teaching (ELT), respectively ESP at the University of Prishtina from the internet, it has to be emphasised that there wasn't a chance to do more precise investigations in all these (and other) departments.

\section{Discussion and Recommendation}

This paper has examined the role of teaching ESP in general and how this course is applied at some departments of the University of Prishtina. The main goal of this research was to analyze the syllabi and to present particular fragments of the syllabi of the different departments of the university, where the used professional and/or General English basic and additional literature is listed (has been exposed), and to make a comparison between them. The findings show that some English teachers use professional course books and also related additional materials from all kinds of resources beneficial to meet the needs of the learners also to equip them with all sorts of job related speaking, reading and writing skills. Unfortunately some others still use General English books, some of them even at elementary level, which cannot be considered as sufficient to deal with future occupational situations. This research was limited by the lack of information on the official website of the University Prishtina about the syllabi, which should have been published and accessible on the internet for all students and others as well.

This research should serve as a general overview showing the facts, and hopefully serve as a motivation for all English teachers to improve ESP courses in all departments of the University of Prishtina "Hasan Prishtina", by using Professional English books for the specific fields of study, by selecting additional related materials, if necessary by consulting experts of the field and by designing their syllabi according to the needs of the students for their future professional occupations.

\section{Conclusion}

Writing this paper, various materials have been studied as well as searching on the internet and other books helped a great deal to accomplish this task, and because ESP is a new and still developing branch in the study of English, it has been attempted to include the main noteworthy parts, like the origins, key notions, characteristics, types and benefits of ESP before writing about the research of ESP at the University of Prishtina.

It is known that English has acquired a unique status among the other languages of the world in that it has been acknowledged as a 'global language', which can also be seen as the main instrument of communication in the diplomatic, political, educational and economic world. So the development of the requirement for English to suit professional, occupational or vocational needs brought English for a particular or specific purpose to light. Now teaching ESP is widespread in many countries of the world, also in the Kosovar public and private universities, however it is facing with obstacles which call for creative solutions. Therefore this research is based on how and if ESP is taught at the University of Prishtina "Hasan Prishtina", respectively in the different departments of it. It presents how the syllabi are designed, what selected literature is used and what effort needs to be conducted, to achieve better results.

To conclude this research it can be stated that ESP courses should be offered to students of all departments, to enable them to increase their learning speed, efficiency and effectiveness, and of course these courses should be 
prepared and carried out properly, so the students will be able to deal with all kinds of situations in their future occupational environment.

\section{References}

Gërmizaj, Sh. \& Hoxha, Sh. (2014). 'Teaching ESP in the University of Prishtina' Hutchinson, T. \& Waters, A. (1987). English for Specific Purposes: A learner-centred approach. Cambridge University Press. Kennedy, C. \& Bolitho, R. (1984). English for Specific Purposes. London: Macmillan. Longman Dictionary of Contemporary English Mackay, R. \& Mountford, A. (Eds.). (1978). English for Specific Purposes: A case study approach. London: Longman. MacKenzie, I. (2010), English for Business Studies 3 rd Edition, Cambridge University Press.

Perren, G. (1974). Forward in Teaching languages to adults for special purposes. CILT Reports and Papers, 11, London: CILT.

Wright, C. (1992). 'The Benefits of ESP' Cambridge Language Consultants. www.camalang.com/art001.htm. Retrieved on May 25th, 2014. 
